\section{ECONOMICS}

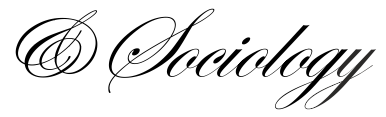

Julia Włodarczyk, Nonneutrality of Money in a Social Perspective, Economics \& Sociology, Vol. 7, No 2, 2014, pp. 199-208. DOI: 10.14254/2071789X.2014/7-2/16

\title{
NONNEUTRALITY OF MONEY IN A SOCIAL PERSPECTIVE ${ }^{1}$
}

\begin{abstract}
The concept of nonneutrality of money is one of the most controversial concepts in the economic theory. Existing theories demonstrate that money is neutral (purely monetary phenomena do not yield real outcomes), but they are based upon assumptions that are unacceptable from the point of view of the complexity of social reality. Rejection of the assumption that the only motive of economic activity is to maximize wealth allows to notice a variety of social, cultural and psychological factors influencing the social meaning and use of money which could be introduced into socio-economic models of monetary phenomena. The aim of this paper is to discuss some results of sociological research linked to the concept of nonneutrality of money. The emphasis is put mostly on the role of individual attitudes toward money. The novelty of this paper consists in linking the concepts of relative deprivation and nonneutrality of money under monetary integration.
\end{abstract}

DOI: $10.14254 / 2071-$

789X.2014/7-2/16

JEL Classification: A12,

D14, D63, E40, Z13

Keywords: money, society, individual attitudes, aggregate relative deprivation.

\section{Introduction}

The concept of nonneutrality of money which implies that purely monetary phenomena may exert pressure on processes occurring within the real sphere of the economy is one of the most controversial concepts in the economic theory. Although the changes in the supply of money alter the structure of relative prices and thus the distribution of income in the economy, these effects are not widely recognized due to a widespread tendency to aggregate macroeconomic variables and demonstrate relationship between changes in aggregate money supply and aggregate price level. Furthermore, the heterogeneity of individual expectations concerning the changes in money supply and inflation rate (closely linked to prevailing uncertainty or at least asymmetry of information) is often not taken into account (cf. Włodarczyk, 2012).

Implications of money being neutral or not refer to a wide range of economic issues, including raison d'être of monetary policy as well as the efficiency of fiscal policy for which it might be important not only to determine how much to spend in aggregate terms, but also who shall receive the transfers to ensure the most efficient use of budgetary means. Somehow

\footnotetext{
${ }^{1}$ This research project was funded by the National Science Centre (decision number DEC2013/09/D/HS4/01157).
} 
against rational economic calculations it turns out that for various reasons one dollar may not necessarily equal one dollar, both in economic (cf. Włodarczyk, 2010; Włodarczyk, 2011) and in social terms (cf. Zelizer, 1989; Zelizer, 1994).

Generally, both economists and sociologists often criticize prevailing monetary theories as being derived from an untenably narrow set of assumptions about the nature of money and types of social action associated with its use (Dodd, 1994, p. VI). In fact, there is a kind of disciplinary schizophrenia in that orthodox economics' precision is based on the assumption that the only motive of human behavior is to maximize wealth, while it is obvious to everyone that real motives underlying economic activity are much more complex (Doyle, 1992, p. 644). Nevertheless, more economists are aware of the social constitution of money, consisting of power and class relationships, socially constructed meaning and symbolic representations of social values (e.g. Wray, 2006, p. 8) and more interdisciplinary research in this field is conducted (e.g. Ingham, 2004; Smithin, 2006).

It is worth mentioning that in the economic theory the first most significant attempt to interpret money as an essential part of the social process requiring holistic approach integrating economic, sociologic, historical, ethnological and statistical aspects was made by Joseph Schumpeter in 1930s. He noted that money usually has different meanings for people of different cultures and its cultural significance shall not be reduced to a common denominator as it is the case of monetary theories which tend to reduce the meaning of money to its functions (Schumpeter, 1991, p. 521).

The aim of this paper is to discuss some results of sociological research that may shed new light on the concept of nonneutrality of money and their possible linkages and implications for economic theory. This paper presents results of preliminary research and therefore is based mostly on the review of sociological and economic literature.

The next section presents a paradigmatic framework for analyzing money in the social reality based upon different assumptions concerning the nature of knowledge and the nature of society. Then the role of social differentiation of money and attitudes toward its use according to individual temperament is investigated. The following section discusses the underpinnings of rejecting the notion of logical and political neutrality of money in sociological literature. Subsequently, a novel link between the social concept of relative deprivation (in aggregate terms) and nonneutrality of money under monetary integration is introduced. Final section concludes.

\section{Money in the social reality}

When analyzing the assumptions underlying economic theories of money it is important to recognize that most of these theories are based on the functionalist paradigm and usually do not take into account a broader context of economic activity. Social theory provides researchers also with other paradigms founded upon different assumptions concerning the nature of knowledge and the nature of society thus allowing for different interpretations of the concept of money (see Table 1). 
Table 1. The role of money in a paradigmatic viewpoint

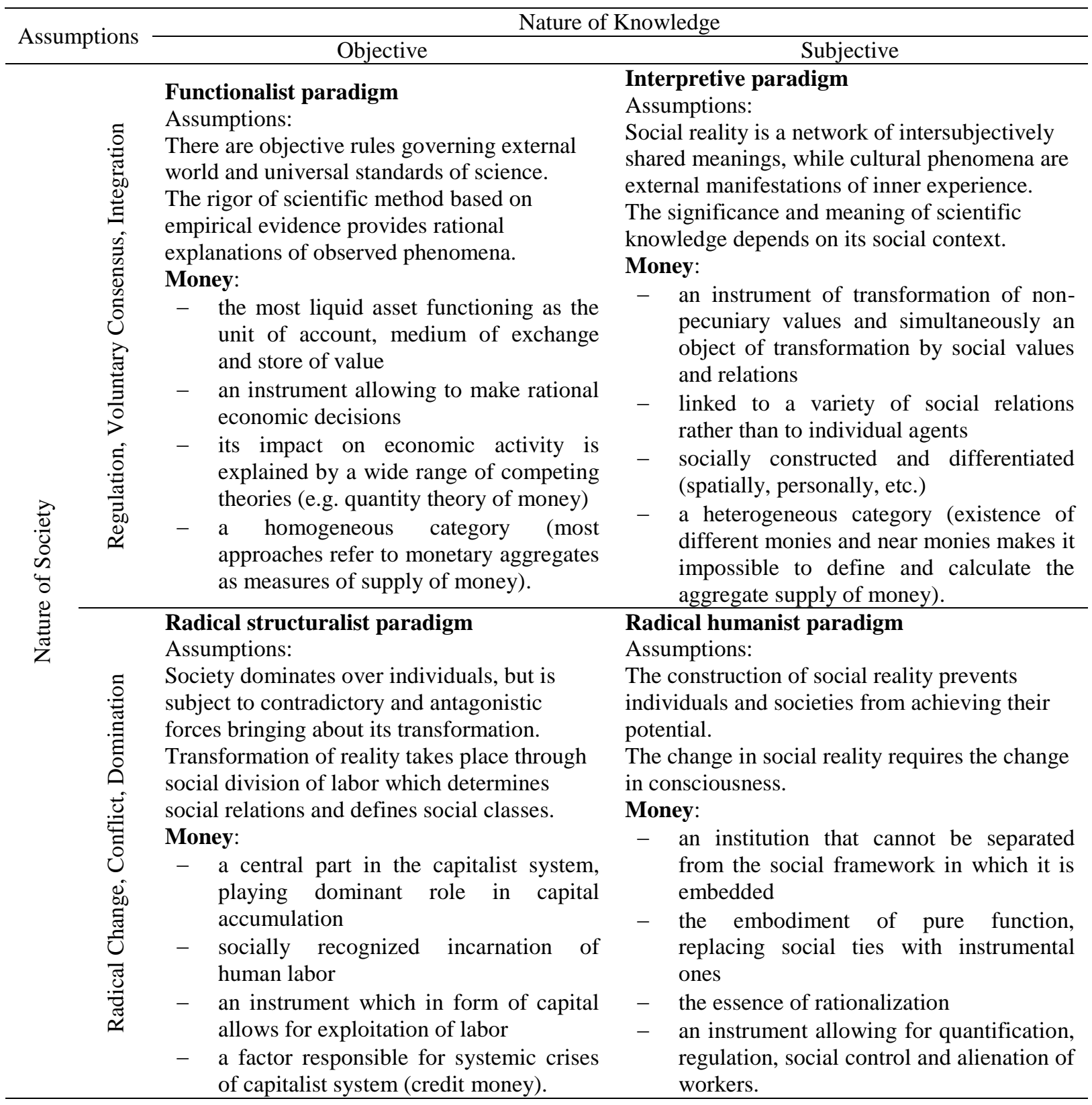

Source: Author's elaboration based on Ardalan (2003).

In accordance with the content of Table 1, it can be stated that in most cases money is not neutral when interpreted as a part of social reality. For instance, money may lead to increased income inequalities as it facilitates capital accumulation and exploitation of labor force (radical structuralist paradigm). Simultaneously, money plays an active role in transforming social values and relations, both in a creative (interpretive paradigm) and in a destructive way (radical humanist paradigm). This interpretation confirms sociological observations that money, similarly to other media of communication, is characterized by two inseparable aspects, namely the integrating (symbolic) and the disintegrating (diabolic) one (Luhmann, 1994, p. 259). 
On the whole, the nature of the multidimensional relationship between money and society can be investigated e.g. in terms of the direction of influence, as well as its context, scale and intensity (see Figure 1).

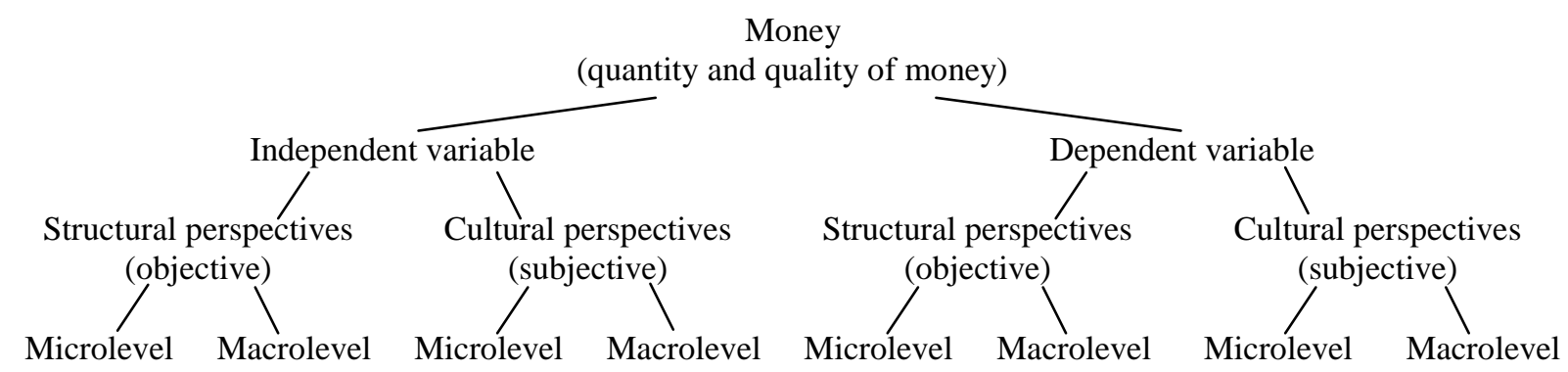

Figure 1. Framework for the sociological analysis of money

Source: Author's elaboration based on Baker \& Jimerson (1992, p. 683).

So far, economists and most of the classical sociologists have usually treated money as an independent variable. However, contemporary sociologists, especially those accentuating cultural perspectives on money, started to analyze it as a dependent variable, shaped by social institutions (Baker \& Jimerson, 1992, p. 682).

Undoubtedly, sociological framework of monetary analyses and their economic applications requires further research regarding all dimensions. Nevertheless, from the point of view of nonneutrality of money, it is worth emphasizing the role of microlevel (disaggregate) analyses which may explain how processes observed in the macrolevel are shaped. Microlevel analyzes can refer to individual preferences and attitudes toward money or to the microlevel underpinnings of evolution of economic and social structures (elaborated in the next sections of the article).

\section{Social differentiation of money and individual attitudes toward money}

Unlike economists, most of sociologists analyze economic and noneconomic uses of money. Therefore, they are able to contrast the prevailing interpretation of money as a homogeneous, infinitely divisible, liquid and qualitatively neutral instrument of commodification of society (Zelizer, 1994, pp. 11-12) with an alternative view of money being shaped by social relations, qualitatively heterogeneous and differentiated for different types of social relations (Zelizer, 1994, pp. 18-19). This opposition can be further elaborated: Money is reductively defined as the ultimate objectifier, homogenizing all qualitative distinctions into an abstract quantity. ... [W] hile money does indeed transform items, values, and sentiments into numerical cash equivalents, money itself is shaped in the process. Culture and social structure mark the quality of money by institutionalizing controls, restrictions, and distinctions in the sources, uses, models of allocation, and even the quantity of money (Zelizer, 1989, p. 342).

In the social reality identical quantities of money may not necessarily be equal or interchangeable. For instance, a $\$ 1,000$ of regular income is not the same money as $\$ 1,000$ borrowed from a friend, not to mention $\$ 1,000$ stolen from a bank (Zelizer, 1989, p. 352). While assigning different meanings and separate uses to particular monies (earmarking), people create different kinds of money (Zelizer, 1994, p. 5). Thus, apart from traditionally analyzed market money, also domestic money (including more specific categories, namely wife's money, husband's money, and children money), gift money and other kinds of money are used frequently. 
From the point of view of contemporary sociologic perspective, money is neither culturally neutral [emphasis added] nor morally invulnerable. It may well "corrupt" values into numbers, but values and sentiment reciprocally corrupt money by investing it with moral, social, and religious meaning (Zelizer, 1989, pp. 347-348).

A deeper analysis of the social meaning of money and how it is attributed leads to subjective, individual interpretations based on psychological factors. For instance, an interesting approach was proposed by Doyle (1999) who linked four temperaments with individual attitudes toward money and typical financial behaviors (see Table 2).

Table 2. Attitudes toward money according to individual temperament

\begin{tabular}{|c|c|c|c|c|c|}
\hline Temperament & $\begin{array}{c}\text { Fear of ... }= \\
\text { Money } \\
\text { as a talisman } \\
\text { against ... }\end{array}$ & $\begin{array}{l}\text { Fear- } \\
\text { reducing } \\
\text { financial } \\
\text { activities }\end{array}$ & $\begin{array}{l}\text { Individual attitude toward } \\
\text { money }\end{array}$ & $\begin{array}{l}\text { Economic } \\
\text { behavior }\end{array}$ & $\begin{array}{l}\text { Attitude } \\
\text { toward risk }\end{array}$ \\
\hline $\begin{array}{l}\text { Melancholic } \\
\text { (Amiable) }\end{array}$ & Abandonment & $\begin{array}{l}\text { GIVE, } \\
\text { Divest }\end{array}$ & $\begin{array}{l}\text { Money is unclean and } \\
\text { harmful to relationships. It } \\
\text { is a fundamental evil and a } \\
\text { source of disappointment. } \\
\text { It should be redistributed. }\end{array}$ & Cooperation & Avoidance \\
\hline $\begin{array}{l}\text { Phlegmatic } \\
\text { (Analytic) }\end{array}$ & Disorder & $\begin{array}{l}\text { SAVE, } \\
\text { Hoard }\end{array}$ & $\begin{array}{l}\text { Money is fundamentally } \\
\text { dirty, but it gives pleasure } \\
\text { to save and control money, } \\
\text { as it provides safety. }\end{array}$ & Exchange & Avoidance \\
\hline $\begin{array}{l}\text { Choleric } \\
\text { (Driver) }\end{array}$ & Incompetence & $\begin{array}{l}\text { TAKE, } \\
\text { Wrest }\end{array}$ & $\begin{array}{l}\text { Money is an instrument of } \\
\text { achieving goals and } \\
\text { accumulation of tangibles. } \\
\text { It allows to exploit others } \\
\text { and thus to reach a higher } \\
\text { rank in the achievement } \\
\text { hierarchy. }\end{array}$ & Competition & Appreciation \\
\hline $\begin{array}{l}\text { Sanguine } \\
\text { (Expressive) }\end{array}$ & Constraint & $\begin{array}{l}\text { SPEND, } \\
\text { Dissipate }\end{array}$ & $\begin{array}{l}\text { Money satisfies the need of } \\
\text { stimulation and novelty. It } \\
\text { allows for an extravagant } \\
\text { behavior and to reach a } \\
\text { higher rank in the } \\
\text { admiration hierarchy. } \\
\text { Money reduces anxiety and } \\
\text { increases freedom. }\end{array}$ & Conflict & Appreciation \\
\hline
\end{tabular}

Source: Author's elaboration based on Doyle (1999, pp. 163-183).

In general, money considerably expands the capacity of individuals to stabilize their own identity by holding something durable that embodies the desires and wealth of all the other members of society (Hart, 2001, p. 259).

Assuming that the basic motive underlying human activities is fear, it is not surprising that people use money as a specific talisman to protect themselves (at least symbolically) from fears that are characteristic of their temperament (Doyle, 1999, p. 163). Obviously, this role of money is relative rather than absolute, because its power as a talisman to relieve fear is incessantly shaped by social and individual experience (Doyle, 1999, p. 188).

To recapitulate, people differentiate money as they do differentiate their social relations. The use of money, especially spare money, is subject to cultural conditionings and 
individual propensities, e.g. people may be willing to spend it on conspicuous consumption, allocate it on the financial market, hoard it at home, give it to a relative or transfer it to a charitable organization.

Conducted considerations shed new light on economic phenomena that potentially may be responsible for nonneutrality of money. For example, indebtedness of a household may not only be the result of its economic situation or asymmetry of information on the financial market, but also it may reflect unresolved domestic conflicts over the use of money (especially in a situation when each household member represents a different type of temperament).

\section{Sociological concepts of logical and political (non)neutrality of money}

Dodd (1994) analyzed and rejected two kinds of neutrality of money which he called logical and political. The former concept refers to the possibility of money to mediate the production and exchange of goods without any intrinsic difference to real economic variables (assuming that the economy is in equilibrium). The latter suggests that although money is used to express inequalities of wealth and power, it is not responsible for generating them (Dodd, 1994, p. 3).

According to the classical and neoclassical economics, money facilitates the production and exchange of goods to proceed more efficiently and extensively as compared with barter exchange. The difference between both kinds of exchange is of quantitative rather than qualitative character. As nothing fundamental changes in the economy due to introduction and circulation of money, money is perceived as a logically neutral instrument (Dodd, 1994, p. 4).

The concept of logical neutrality of money is directly linked to the quantity theory of money. Although a detailed presentation of the quantity theory of money is outside the scope of this article, it is worth repeating that it does not take into account structural factors determining the flow of money through the economy, nor individual perceptions, attitudes and uses of money (e.g. it assumes that savings are automatically and immediately turned into investment, thus excluding hoarding and similar behaviors), nor broader moral, cultural and institutional conditions (Dodd, 1994, p. 11).

All these observations allow to state that: Money is not simply a neutral [emphasis added], transparent token mediating the exchange of goods and services as classical and neoclassical theories suggest, but has cultural and symbolic associations generated by its use as a form of wealth and as a foundation of power, its conceptualization in relation to freedom, happiness and morality, and its retention as a basis for confidence or simply for its own sake. It seems incurably naive to suggest that such a range of attitudes towards the acquisition and use of money should be depicted on the basis of a logical relationship between the quantity of money and the level of prices (Dodd, 1994, p. 13).

Apart from confusions over perceptions of money and its meaning, the roots of money's disruptive role may be seen in the organization of power in economic life which seem to be responsible for the lack of the political neutrality of money (Dodd, 1994, p. 13).

The structural relationship between money, capital and the distribution of power in the capitalist system was one of the central issues in works of radical economists. For instance, according to Marx, money does not merely express exchange relationships as such, but appears as a crystallization of capitalist relations of production and their structural underpinnings. Money ceases to be neutral, because instead of coordinating activities of independent producers within the social division of labor, it becomes an instrument by which labor is commodified in an abstract form, bought and sold on the labor market, paid with wage, and simultaneously exploited for the accumulation of profit (Dodd, 1994, pp. 14-15). 
There are also other researchers that do not perceive money as a neutral instrument which can be changed without any fundamental effects on the price system. In fact, money can be treated as a weapon in the struggle of a man against man, with prices being expressions of relative chances in this struggle of interest (Weber, 1978, p. 108). As a consequence of this nonneutrality of money, workers have lost control over the goods they produce and cannot even buy them back. Their wages are lower than the value of the goods produced, because the aim of economic activity is to make profit (Mellor, 2010, p. 20).

Theoretically, [t]he inherent transparency of money in relation to the will of its holder is, by definition, non-discriminating. The possession of money is empowering irrespective of the wealth, property, class position and social and political status of its holder. ... In practice, however, these features are almost invariably obscured. A monetary income which barely meets the purchase of subsistence presents a starkly different set of choices to its holder than money held over and above this requisite level. Money acquired in the form of a windfall or gift can give rise to a series of possibilities which are markedly distinct from money routinely gained in the form of income, where most if not all of its potential uses may already have been accounted for by regular economic obligations or commitments. What can be achieved through money can also depend on pre-existing networks of relationships, on differential degrees of access to the acquisition of goods and services not accounted for by the price mechanism alone. ... These inconsistencies in the empowering features of money are structurally interconnected with the distribution of wealth and power in society and across the global economy. There is, then, a clear incongruity in the transparency of money as conceived in principle as opposed to the empowering features it actually possesses in practice (Dodd, 1994, pp. 159-160).

The opposition between transparency of money, which in ideal conditions should be one of the manifestations of its neutrality, and real inequalities associated with its empowering features seem to be very important for the sociological interpretations of the nonneutrality of money. In the next section this opposition will be further investigated by means of the sociological concept of relative deprivation in aggregate perspective.

\section{Aggregate relative deprivation and nonneutrality of money under monetary integration}

Social perceptions of money and its use discussed in previous sections of this paper may constitute and important channel of transmission of monetary impulses on the real sphere of the economy. This section focuses on the process of monetary integration in order to exemplify how social reactions to economic processes involving money may lead to changes in output and employment.

Assuming that there is a given number countries, each of them characterized by a fixed supply of money and their own currency, a purely qualitative change concerning supply of money (e.g. conversion of domestic currencies into a common one without any quantitative changes in the aggregate supply of money) is likely to have a significant impact on the whole economy.

First of all, if there are heterogeneous attitudes toward a new currency, a change in economic behavior of individuals may occur, because the psychological rate of conversion of one currency into another might be significantly different from the official one. As a consequence, short or even medium term distortions in monetary circulation and the real sphere may be observed.

Secondly, heterogeneous preferences may also refer to the country of origin of goods. If this is the case, it may be socially beneficial not to resign from national currencies which may help to achieve a more differentiated production structure and a more efficient allocation of resources. In other words, a successful introduction of a common currency may depend on 
the scale of consumers' indifference toward the origin of goods being bought (Kocherlakota \& Krueger, 1999).

Finally, introduction of a common currency means an instantaneous revision and expansion of social space in which interpersonal comparisons of incomes take place (which is directly linked to transparency of money mentioned in the previous section). Obviously, even without the introduction of a common currency cross-border income comparisons are also possible, but they are associated with higher costs, and therefore are probably less frequent.

The starting point of analysis conducted in this section is that income comparisons bear on wellbeing and that social stress can be measured by aggregate relative deprivation $(A R D)$ which is the sum of the levels of stress experienced by the individuals who constitute the population (cf. Stark, 2010; Stark, 2013). It is also assumed that initially income comparisons are conducted within country borders and after joining the monetary union they encompass all individuals from merging economies.

In case of income-based comparisons, the aggregate relative deprivation of a population of $n$ members (assuming that the population can be identified with the comparison group), ordered by their incomes $x_{i}\left(x_{i} \leq x_{j}\right.$ for $\left.i<j\right)$, is equal to:

$$
A R D(x)=\sum_{i=1}^{n} R D\left(x_{i}\right)=\frac{1}{n} \sum_{i=1}^{n} \sum_{j=i+1}^{n}\left(x_{j}-x_{i}\right)
$$

where $R D\left(x_{i}\right)$ is the relative deprivation experienced by individual $i$ (it is the sum of the extra income units that others in the population get, normalized by the size of the population).

Introduction of a common currency can have a positive or negative impact on a country's aggregate relative deprivation. In particular, when a low income population merges with a high income population (provided that there is no overlap between income distributions of both populations), all the individuals in the high income population except for the richest individual gain in terms of relative deprivation, but all the individuals in the low income population suffer (Stark \& Włodarczyk, 2013).

Potentially, there are severe economic consequences of the increase in social stress measured by aggregate relative deprivation in the low income population which include e.g. increased inflationary pressure (if the $A R D$ impulse is translated into successful wage increase requests), increased fiscal pressure (if dissatisfied individuals are able to extort more transfers from the budget), and lower competitiveness of the economy (if individuals decide to exert lower effort and reduce productivity or if the increase of inflationary or fiscal pressure is significant enough to influence the real exchange rate) ${ }^{2}$. The final outcome may strongly depend on individual interpretations and attitudes toward the whole process.

Furthermore, if in $A R D$ terms monetary integration is a source of positive stimulus for the high income population, the output gap between low income and high income population is likely to widen over time. Thus monetary integration of populations differentiated in terms

\footnotetext{
${ }^{2}$ Preliminary estimates based on methodology presented in Stark \& Włodarczyk (2013) and Eurostat data (2014) extracted for 12 countries that adopted euro in 1999 and 2001 show a statistically significant correlation between cumulative gains from euro adoption in $A R D$ categories (calculated for each country as the sum of differences between hypothetical value of $A R D$ without adopting the euro and $A R D$ when in the EMU) and cumulative rise in the price level, as well as a statistically significant correlation between cumulative gains from euro adoption in $A R D$ categories and cumulative rise in the real effective exchange rate over the period 1999-2011. In the former case the correlation coefficient was equal to -0.75 (thus implying that countries experiencing greater " $A R D$ losses" were also characterized by higher inflation rates), while in the latter case the correlation coefficient was equal to -0.69 (which means that countries experiencing greater " $A R D$ losses" observed also stronger appreciation of the real effective exchange rate). However, there was no linear relationship between cumulative gains from euro adoption in ARD categories and cumulative budgetary deficits over the period 1999-2011.
} 
of income may in fact lead to the polarization and social disintegration of the whole monetary union.

It is also important to emphasize that in terms of aggregate relative deprivation the overall effect of integration is always negative, because if individuals' incomes are held constant, the $A R D$ of the merged population is greater than the sum of the levels of $A R D$ of the constituent populations before the merger (Stark, 2013). This means that even if a system of transfers from high income economies (characterized by "ARD surpluses") to low income economies (characterized by "ARD deficits") was established, it would not prevent widening the gap between high income and low income countries.

Undoubtedly, the advantage of referring to the concept of aggregate relative deprivation is that it allows to link purely qualitative changes in the supply of money with social welfare and that it can be introduced into economic models to verify its usefulness.

\section{Conclusions}

According to the sociological literature, money is a complex socio-economic phenomenon, enmeshed in dialectics of its quantitative and qualitative characteristics, socially constructed and individually perceived, used for various economic and noneconomic purposes, and therefore quite distinct from its purely instrumental and neutral economic representation. Making economic theories of money more realistic may require not only alteration of the set of underlying assumptions, but maybe also a paradigmatic change. This paper pointed out several ways to bridge the gap between existing theories and the social reality, but as was mentioned in the introduction this was only a first step toward integration of economic and sociological concepts of money. Certainly, the need of a socio-economic analysis of money reflects the embeddedness of economic activity in social, cultural and political structures.

In line with conducted considerations, apart from construction of economic models including the aggregate relative deprivation, further research could investigate e.g. the link between the heterogeneity of social structures (in terms of domination of different types of temperament and financial behaviors) and possible outcomes of monetary integration, the link between the nonneutrality of money and the institutional structure of banking system due to its important role in the organization of power in society, the extent to which money is responsible for diffusion of uncertainty and other issues. Besides, increasing dynamics of international migration and international transfers, including personal remittances is likely to bring about growing interest in cross-cultural research investigating differences in the use of money across the borders.

\section{References}

Ardalan, K. (2003), Money and academic finance: The role of paradigms, International Journal of Social Economics, Vol. 30, No. 6, pp. 720-740.

Baker, W.E, Jimerson, J.B. (1992), The sociology of money, The American Behavioral Scientist, Vol. 35, No. 6, pp. 678-693.

Dodd, N. (1994), The Sociology of Money: Economics, Reason and Contemporary Society, Polity Press, Cambridge.

Doyle, K.O. (1992), Introduction: Money and the behavioral sciences, The American Behavioral Scientist, Vol. 35, No. 6, pp. 641-657.

Doyle, K.O. (1999), The Social Meanings of Money and Property: In Search of a Talisman, Sage Publications, Thousand Oaks - London - New Delhi.

Eurostat (2014), http://epp.eurostat.ec.europa.eu (data extracted on May, 12). 
Hart, K. (2001), Money in an Unequal World, Texere, New York - London.

Ingham, G. (2004), The Nature of Money, Polity Press, Cambridge, UK - Malden, Massachusetts.

Kocherlakota, N., Krueger, T. (1999), A signaling model of multiple currencies, Review of Economic Dynamics, Vol. 2, pp. 231-244.

Luhmann, N. (1994), Die Wirtschaft der Gesellschaft, Suhrkamp Verlag, Frankfurt am Main.

Mellor, M. (2010), The Future of Money. From Financial Crisis to Public Resource, PlutoPress, London - New York.

Schumpeter, J.A. (1991), Money and currency, Social Research, Vol. 58, No. 3, pp. 499-543.

Smithin, J. (ed.) (2006), What is money? Routledge, London - New York.

Stark, O. (2010), Looking at the integration of nations through the lens of the merger of populations: Preliminary superadditivity and impossibility results, Swiss Journal of Economics and Statistics, Vol. 146, No. 4, pp. 661-675.

Stark, O. (2013), Stressful integration, European Economic Review, Vol. 63, pp. 1-9.

Stark, O., Włodarczyk, J. (2013), European monetary integration and aggregate relative deprivation: The dull side of the shiny euro, mimeo.

Weber, M. (1978), Economy and Society: An Outline of Interpretive Sociology. University of California Press, Berkeley - Los Angeles - London.

Włodarczyk, J. (2010), Efektywność przepływów pieniężnych w perspektywie systemowej, in: H. Buk, C.M. Olszak, E. Ziemba, M. Rówińska (eds.): Ekonomia, finanse: Współczesne wyzwania i kierunki rozwoju, CBiE, Katowice, pp. 543-560.

Włodarczyk, J. (2011), Koncentracja i rozpraszanie pieniądza w systemie fiskalnym, Nierówności społeczne a wzrost gospodarczy, Vol. 19, pp. 67-77.

Włodarczyk, J. (2012), Strukturalno-informacyjne aspekty braku neutralności pieniądza, Studia Ekonomiczne. Zeszyty Naukowe Uniwersytetu Ekonomicznego w Katowicach, Vol. 84, pp. 197-208.

Wray, L.R. (2006), Banking, finance and money: A socioeconomics approach, Working Paper No. 459, The Levy Economics Institute of Bard College, University of Missouri.

Zelizer, V.A. (1989), The social meaning of money: "Special monies", American Journal of Sociology, Vol. 95, No. 2, pp. 342-377.

Zelizer, V.A. (1994), The Social Meaning of Money, Basic Books, New York. 